\title{
Paleo-stress orientations and magnitudes from triaxial testing and stress inversion analysis in Nankai accretionary prism sediments
}

\author{
Yoshitaka Hashimoto ${ }^{1 *}$, Michael Stipp ${ }^{2}$, Jonathan C. Lewis ${ }^{3}$ and Frank Wuttke ${ }^{4}$
}

\begin{abstract}
Combined knowledge on the magnitude as well as the orientation of paleo-stress is usually not given. Based on drilling investigations and laboratory experiments, we are able to provide both, constraints on paleo-stress magnitude as well as orientation in the shallow part of the Nankai accretionary wedge at Sites C0001 and C0002 of the Integrated Ocean Drilling Program (IODP) Nankai Trough Seismogenic Zone Experiment (NanTroSEIZE). Slip data of core-scale faults indicate multiple paleo-stress geometries, including normal, strike-slip, and reverse faulting regimes. Combining new and previously obtained results from triaxial compressional tests that constrain internal friction angles at critical state with the paleo-stress inversion results, we examine paleo-stress magnitudes for each stress state at each site. We observe that the paleo-stress magnitude for the normal faulting regime is smaller than that for the reverse faulting regime, although the paleo-stress magnitude for Site C0002 is not well-constrained. The change in stress magnitude may reflect changing horizontal tectonic stresses transmitted to the accretionary wedge from changing friction conditions along the subduction plate interface and in turn may have implications for the evolution of the accretionary wedge and/or the seismic cycle.
\end{abstract}

Keywords: Paleo-stress state, Paleo-stress magnitude, Nankai accretionary wedge, NanTroSEIZE

\section{Introduction}

The state of stress in a subduction zone system exerts important controls on accretionary wedge architecture, intra-wedge fault development, and seismic behaviors along the megathrust plate boundary and splay faults (e.g., Wang and Hu 2006; Lin et al. 2013; Schumann et al. 2014a). The critical taper of a wedge is controlled by basal friction, wedge strength, gravitational body forces, and tectonic driving forces. These parameters evolve with time during geological time scale and/or seismic cycling (e.g., Wang and Hu 2006; Lin et al. 2013; Schumann et al. 2014a).

The contemporary stress state within the shallow portion of an accretionary prism can be obtained by borehole observations (Chang et al. 2010; Zoback et al. 2003) or anelastic strain recovery (ASR) measurements on core

* Correspondence: hassy@kochi-u.ac.jp

'Kochi University, Akebonocho 2-5-1, Kochi 780-8520, Japan

Full list of author information is available at the end of the article samples (e.g., Lin et al. 2007; Wu et al. 2007; Chang et al. 2010; Lin et al. 2015). At the Nankai trough, recent studies have integrated borehole and ASR results with constraints on material properties to conclude that the stress state for the shallow portion of the wedge is consistent with a normal faulting regime with vertical maximum principal stress (e.g., Byrne et al. 2009; Lin et al. 2015; Kitajima et al. 2017; Oohashi et al. 2017).

Paleo-stress can be constrained for faults of unknown age by stress (or alternatively strain) inversion methods (e.g., Angelier 1984; Yamaji 2000). At the Nankai subduction zone, this has been done for older, exhumed parts of the accretionary wedge (Hashimoto et al. 2014, 2015) revealing the predominance of normal faulting at the deeper structural level of the Cretaceous accretionary wedge. Lewis et al. (2013) examined the paleo-stress state in the shallow Nankai accretionary wedge by inverting core-scale faults in paleomagnetically reoriented cores. They found stress geometries indicative of 
normal faulting, but also strike-slip and thrust faulting in the shallow portion of the accretionary wedge. Hashimoto et al. (2015) employed a stress polygon approach that has been used to constrain modern accretionary wedge stress magnitudes (Zoback et al. 2003), to determine paleo-stress magnitude in cores recovered from the Chelungpu Fault drilling project in Taiwan. They found that normal faulting regimes were characterized by smaller stress magnitudes than those of reverse faulting regimes. The same approach can be applied to the multiple types of paleo-stress regimes in the shallow portion of the Nankai accretionary wedge which Lewis et al. (2013) has revealed.

In this study, we constrain paleo-stress magnitudes at sites C0001 and C0002 by combining paleo-stress inversion results for core-scale faults (i.e., partial stress tensors) with laboratory-derived internal friction values for core samples at critical state. The latter is used specifically to provide constraints on the size of the stress polygons for each faulting regime. Finally, we discuss the implications of the differences in stress magnitude for different faulting regimes in the shallow portion of the Nankai accretionary wedge, especially in the context of plate boundary processes and the seismic cycle.

\section{Structural and stratigraphic setting}

The study area is located at the Nankai Trough where the Philippine Sea plate subducts beneath the Amurian plate at a rate of $\sim 4.1-6.5 \mathrm{~cm} /$ year (Fig. 1a) (Seno et al. 1993; Miyazaki and Heki 2001; Kimura et al. 2018). Drilling and coring for the Integrated Ocean Drilling Program (IODP) Nankai Trough Seismogenic Zone Experiment (NanTroSEIZE) have been conducted since 2007 at multiple sites off Kii Peninsula (Fig. 1a) (e.g., Tobin et al. 2009; Ashi et al. 2009). In this study, we have taken advantage of samples from three drilling sites to perform triaxial compression experiments to determine strength characteristics for these sediments at the critical state (Fig. $1 \mathrm{~b}$ and Table 1). Sediments from the shallower portion of each site are composed of silty clay and clayey silt with interbedded volcanic ash at site C0001; silty clay with a substantial component of calcareous nannofossils, siliceous biogenic debris, and volcanic ash at site C0008; and silt clay, sand, silty sand, and rare volcanic ash at site C0006. In this study, we used silty clay from less than $100 \mathrm{~m}$ below seafloor (Table 1) from sites C0001, C0006, and $\mathrm{C0008}$ because these materials are thought to reflect typical pre-faulting material properties. The most shallow samples are of Pleistocene age.

Kinematic data of core-scale faults are from sites C0001 (upper slope site) and C0002 (forearc basin site) taken from Lewis et al. (2013). We have inverted for stress using the method of Yamaji et al. (2006). Core-observations provide kinematic constraints and indicate a spectrum of fault types, including normal and thrust faults at site C0001, and normal, strike-slip, and thrust faults at site $\mathrm{C0002}$ (see black arrows in Fig. 2). The fault data come from cores retrieved from 146 to $458 \mathrm{~m}$ (Pleistocene to Pliocene in age) and 929-1042 m (mainly Miocene in age) for sites C0001 and C0002, respectively (Lewis et al. 2013).

\section{Methods/Experimental \\ Laboratory experiments}

We performed laboratory triaxial compression tests on unfaulted core samples that were selected as being representative of the lithologies that host our fault data set. Two different test types were carried out to establish the mechanical characteristics of these silty clay samples, single step, and pressure stepping compression tests (cf. Stipp et al. 2013). Cylindrical samples with $50 \mathrm{~mm}$ in diameter and approximately 60 $\mathrm{mm}$ in length were used for triaxial deformation (Fig. 3). The standardized sample's height/diameter ratio (H/D ratio) is 2 for axial compression tests (American Society for Testing and Materials (ASTM), D4767). The small H/D ratio of the investigated samples (approximately 1.2) in this study tends to result in slightly higher shear strength (e.g., ASTM, C42/C 42M-03). However, the effect of H/D ratio on shear strength is variable depending on sample composition, consolidation state, and other parameters. Each experiment consists of three different experimental stages: saturation, consolidation, and deformation. In the saturation stage, the samples were subjected to a confining pressure of $300-450 \mathrm{kPa}$ and a pore-fluid/ back pressure of $280-380 \mathrm{kPa}$ to saturate the samples under drained and hydrostatic condition $\left(\sigma_{1}=\sigma_{2}=\sigma_{3}\right)$ for at least $24 \mathrm{~h}$. Confining pressure and pore pressure of the subsequent experimental stages depend on the saturation conditions. In the consolidation stage of the pressure stepping tests, samples were consolidated under hydrostatic condition at $400-500 \mathrm{kPa}$ confining pressure and at a $100 \mathrm{kPa}$ lower back pressure/pore-fluid pressure. In the single step compression tests, confining pressure was at $700 \mathrm{kPa}$ or 1000 $\mathrm{kPa}$ for the consolidation and the successive deformation stage (Table 1). In the pressure stepping compression tests, confining pressures were applied for three different steps at $400-500 \mathrm{kPa}, 700-750 \mathrm{kPa}$, and $1000 \mathrm{kPa}$ for consolidation and also the successive deformation stages (Table 1). Consolidation was conducted under drained condition. In the deformation stage, axial displacement and hence deformation was applied under consolidated undrained conditions 


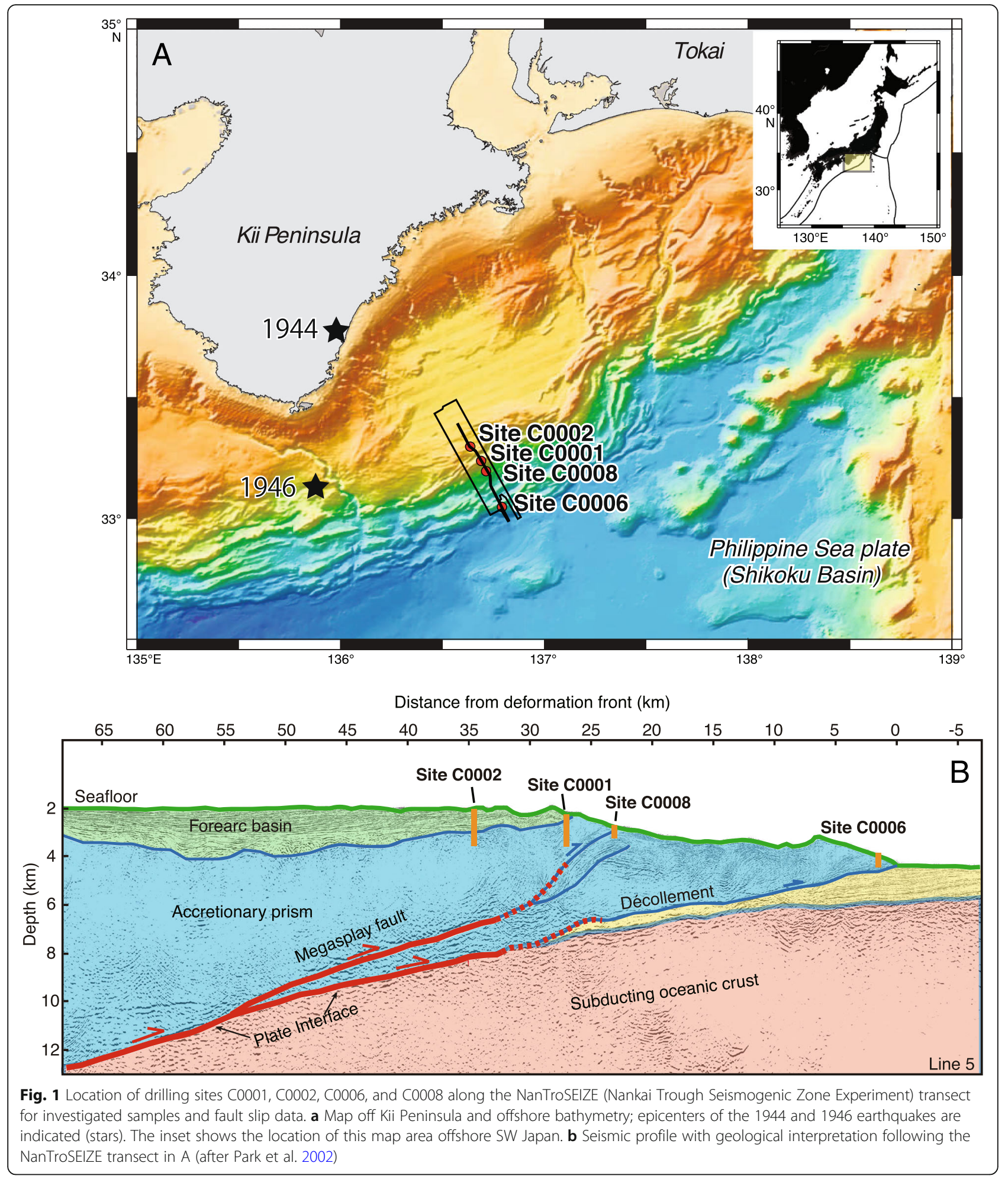

at a displacement rate of $0.01 \mathrm{~mm} / \mathrm{min}$. During deformation, axial displacement, confining pressure, fluid pressure, and axial stress were recorded. Experiments were carried out at room temperature. In the single step tests, axial strain of $~ 35-45 \%$ were achieved when the differential stress record has passed peak stress (yield strength) and approached a residual value (critical state). In the pressure stepping tests, axial 
Table 1 Sample list, settings of laboratory tests, and internal friction results. Data of core samples C0001E11H-1, C0006E8H-1, and C0008A9H-3 are taken from Stipp et al. (2013)

\begin{tabular}{|c|c|c|c|c|c|c|c|c|}
\hline \multirow[t]{2}{*}{ Sample } & \multirow[t]{2}{*}{ Depth (mbst) } & \multirow[t]{2}{*}{ Porosity (\%) } & \multicolumn{3}{|c|}{ Single compression tests } & \multicolumn{3}{|c|}{ Pressure stepping compression tests } \\
\hline & & & $\begin{array}{l}\text { Confining } \\
\text { pressure }\end{array}$ & $\begin{array}{l}\text { Fluid } \\
\text { pressure }\end{array}$ & $\begin{array}{l}\text { Slope at } \\
\text { critical stage }\end{array}$ & Confining pressure & $\begin{array}{l}\text { Fluid pressure } \\
\text { at initial compaction }\end{array}$ & $\begin{array}{l}\text { Slope at } \\
\text { critical state }\end{array}$ \\
\hline $\mathrm{C} 0001 \mathrm{E} 6 \mathrm{H}-1$ & 43.01 & 62.1 & $700 \mathrm{kPa}$ & $450 \mathrm{kPa}$ & 0.56 & $500 \mathrm{kPa}, 750 \mathrm{kPa}$ and $1000 \mathrm{kPa}$ & $300 \mathrm{kPa}$ & 0.68 \\
\hline C0001E11H-1 & 90.62 & 61.7 & $1000 \mathrm{kPa}$ & $300 \mathrm{kPa}$ & 0.68 & $400 \mathrm{kPa}, 700 \mathrm{kPa}$ and $1000 \mathrm{kPa}$ & $300 \mathrm{kPa}$ & 0.57 \\
\hline C0006E8H-1 & 48.23 & 48.9 & $1000 \mathrm{kPa}$ & $300 \mathrm{kPa}$ & 0.76 & $400 \mathrm{kPa}, 700 \mathrm{kPa}$ and $1000 \mathrm{kPa}$ & $300 \mathrm{kPa}$ & 0.81 \\
\hline $\mathrm{COOOBA9H-3}$ & 76.06 & 52.2 & $1000 \mathrm{kPa}$ & $300 \mathrm{kPa}$ & 0.57 & $400 \mathrm{kPa}, 700 \mathrm{kPa}$ and $1000 \mathrm{kPa}$ & $300 \mathrm{kPa}$ & 0.68 \\
\hline $\mathrm{C} 0008 \mathrm{C} 11 \mathrm{H}-3$ & 83.09 & 60.0 & $700 \mathrm{kPa}$ & $300 \mathrm{kPa}$ & 0.69 & $500 \mathrm{kPa}, 750 \mathrm{kPa}$ and $1000 \mathrm{kPa}$ & $400 \mathrm{kPa}$ & 0.81 \\
\hline
\end{tabular}

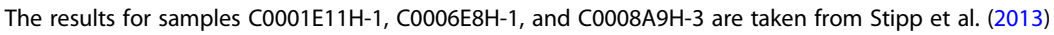

displacement was stopped just at or before the peak stress in the first two steps, while in the third step deformation was continued passed peak and to residual stress reaching total axial strains of up to $40 \%$ (cf. Stipp et al. 2013). After each pressure step, a new consolidation stage at the elevated confining pressure level was conducted. Characteristic stress-strain curves are shown in Fig. 4. Similar results on NanTroSEIZE samples have been presented by Stipp et al. (2013).

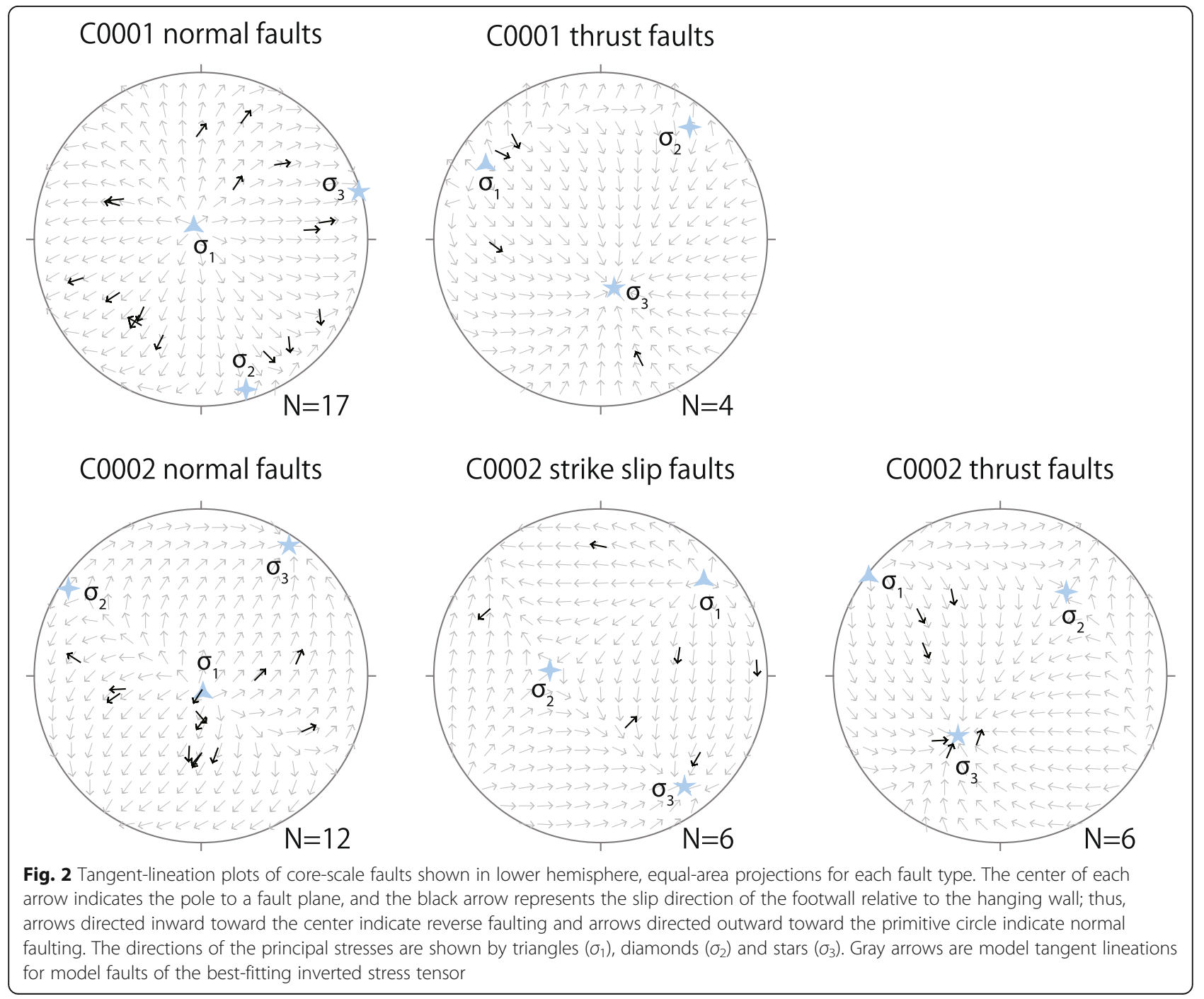



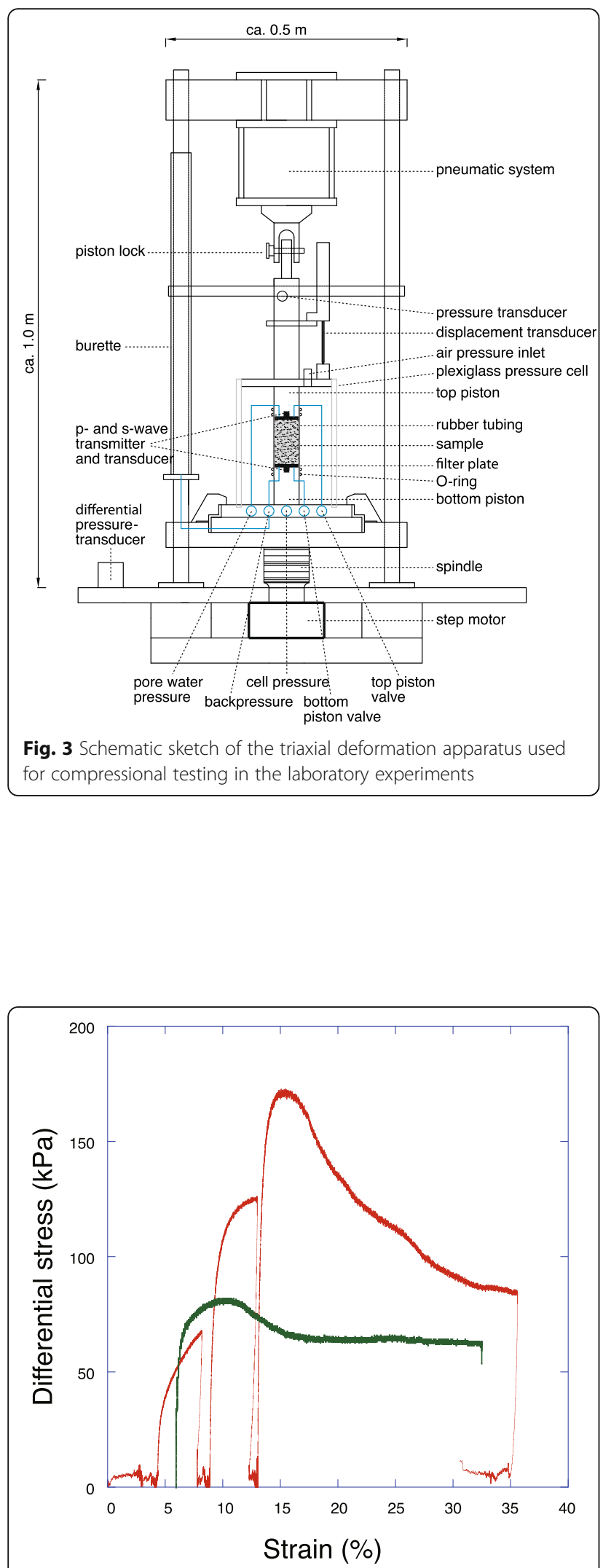

Fig. 4 Differential stress/strain curves for single compression test (dark green) and pressure stepping test (red) from sample C0001E6H-1

\section{Core-scale fault inversion}

We adopted the Hough transform method to invert the core-scale faults for paleo-stress orientations and stress ratio (Yamaji et al. 2006). The stress ratio is defined as

$$
\Phi=\frac{\sigma_{2}-\sigma_{3}}{\sigma_{1}-\sigma_{3}}
$$

where $\sigma_{1}, \sigma_{2}$, and $\sigma_{3}$ are the maximum, intermediate, and minimum principal stress, respectively. This method uses a statistical basis for separating stresses from heterogeneous fault slip data (Yamaji et al. 2006). In the case that the number of slip data is very limited as like in this study, it is difficult to find a single optimal solution. The Hough transform method is one of the multiple inversion methods (Yamaji 2000), which gives multiple solutions picking some faults repeatedly from the total number of faults to form clusters. The Hough transform method would provide the probability for each solution if multiple solutions were obtained, on the basis of the peak height of clusters. In this study, we took the most probable solution as the representative paleo-stress for each fault type at each drilling site. We used the Hough transform inversion software named "him" (http://www.kueps.kyoto-u.ac.jp/ web-bs/k_sato/ software/him.zip) for the processing of fault slip data and peak picker provided with him to detect the most probable solution of stress state.

\section{Results}

\section{Results of laboratory experiments}

In this study, the relationships between effective mean stress (average of effective axial and confining pressures) and the maximum shear stress (differential stress of $\sigma_{1}$ and $\sigma_{3}$ divided by 2) were examined (Fig. 5). The results provide absolute strength constraints that we adopt to explore possible stress configurations using stress polygons (e.g., Chang et al. 2010). Samples were recovered from sites C0001, C0008, and C0006 at the upper slope to frontal thrust zone as described (Table 1). These samples were collected from a depth range of less than $100 \mathrm{~m}$. Porosity of the samples ranges from 49 to $62 \%$ (Table 1 ).

The results of pressure stepping and single step compression tests are presented in Fig. 5 in black and red curves for each sample, respectively. After starting deformation, differential stress and fluid pressure increase with axial displacement, each test was performed under undrained conditions. The relationship between effective mean stress and the maximum shear stress shows a curved shape due to the increase in fluid pressure. Linear relationships between effective mean stress and the maximum shear stress are observed after the yield point where samples have reached a critical state (Fig. 5). Slopes at critical state in the maximum shear stress versus mean stress space obtained from the laboratory tests 


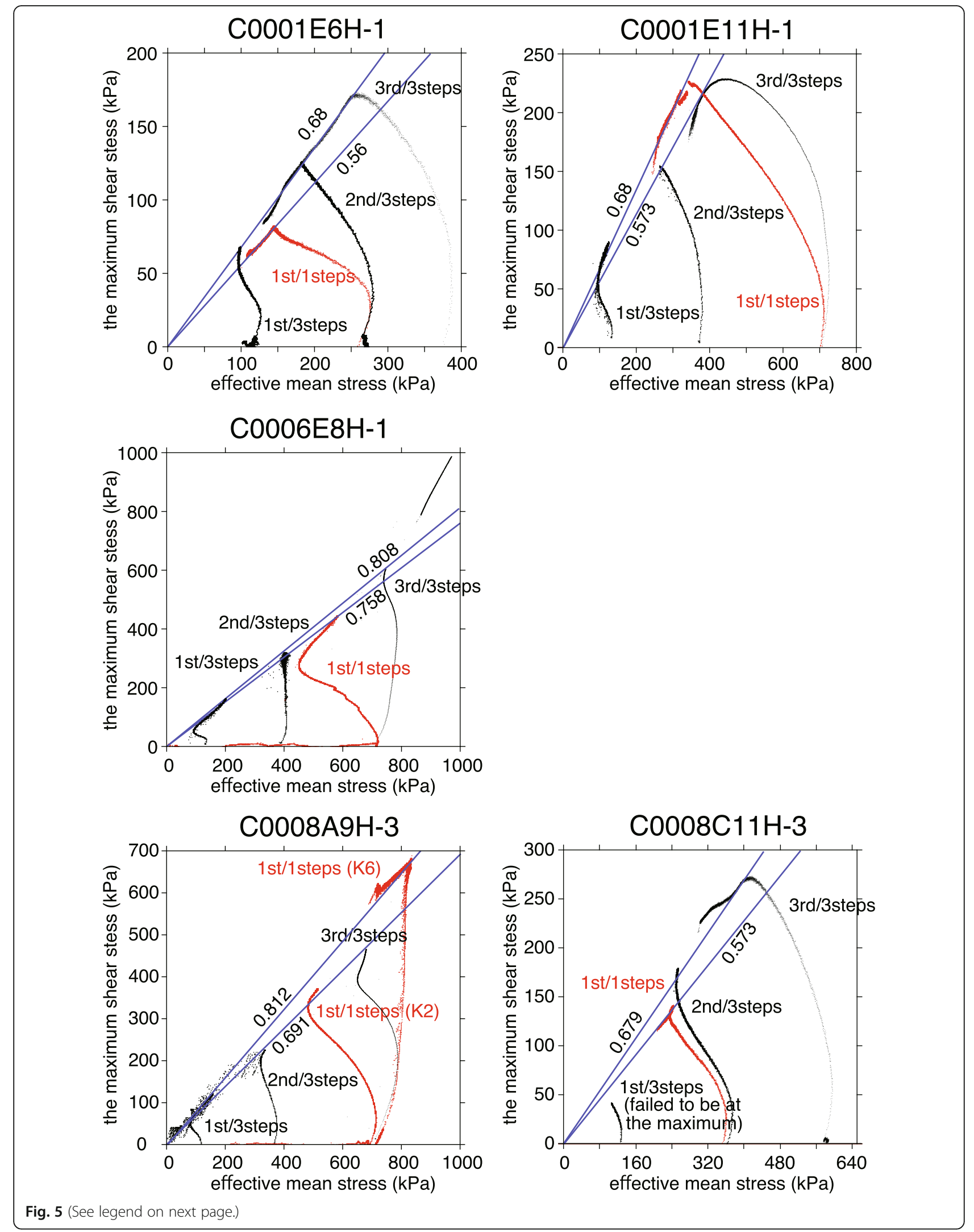


(See figure on previous page.)

Fig. 5 Relationship between effective mean stress and the maximum shear stress for each sample. The results of single compression tests and pressure stepping tests are indicated by red dots and black dots, respectively. Experimental run numbers of the study of Stipp et al. (2013;

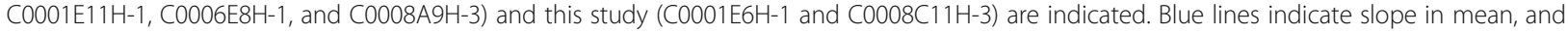
the maximum shear stresses at critical state

range between $0.56-0.76$ and $0.57-0.81$ for single step compression and pressure stepping compression tests, respectively (Fig. 5 and Table 1).

The variations in critical slope angles might be controlled by initial micro-scale fabrics (i.e., textures or crystallographic preferred orientations) of sediments as discussed by Schumann et al. (2014b). The differences between the single step compression and pressure stepping compression tests might also be caused by small variations in sample composition. Alternatively, in the pressure stepping tests, samples were already microstructurally modified within the first and second step by internal deformation even before peak stress. This is, of course, not critical for the single step compression tests. Nevertheless, there are only slight deviations between the data sets of the two different testing procedures, but relatively large variations for each of the two procedures. Based on the data, we used the slope variation at critical state ranging from 0.55 to 0.80 as a representative range for the sediments of the Nankai accretionary wedge. Because the slope variation at critical state shows the same range as the results of Stipp et al. (2013), we use an internal friction $\mu$ of $0.45-0.62$, corresponding to $24.6^{\circ}-28.7^{\circ}$ of internal friction angle determined by Stipp et al. (2013) for the construction of the stress polygons as describe below.

\section{Results of core-scale fault inversion analysis}

The results of core-scale fault inversion are presented in lower hemisphere equal-area stereoplots for each fault setting and site (Fig. 2 and Table 2). For normal faults at site C0001, vertical $\sigma_{1}$ and ENE horizontal $\sigma_{3}$ with a stress ratio of 0.1652 were obtained. Conversely, vertical $\sigma_{3}$ and NW horizontal $\sigma_{1}$ with a stress ratio of 0.8579 were obtained for thrust faults in C0001 (Fig. 2 and Table 2). Similarly, for normal, strike-slip and thrust faults at site C0002, vertical $\sigma_{1}$ and NE horizontal $\sigma_{3}$ with a stress ratio of 0.667 , NE horizontal $\sigma_{1}$ and
SE horizontal $\sigma_{3}$ with a stress ratio of 0.3609 , and slightly SW-plunging $\sigma_{3}$ and NW horizontal $\sigma_{1}$ with a stress ratio of 0.6436 were identified, respectively (Fig. 2 and Table 2). Although the number of slip data is small in some cases, all of the obtained principal stress orientations are basically consistent or complementary for $\sigma_{1}$ and $\sigma_{3}$ in the directions NE and/or NW with slight variations. The results correspond to the data from Lewis et al. (2013), and they are also consistent with the present horizontal principal stress directions estimated from borehole investigations (e.g., Lin et al. 2015).

\section{Discussions}

\section{Constraints on paleo-stress magnitude}

Constraints on paleo-stress magnitude were derived using the same method as applied by Hashimoto et al. (2015), combining the paleo-stress from core-scale fault inversion and from stress polygons. The relationship between stress ratio and friction limit is expressed as

$$
\frac{\sigma_{1}}{\sigma_{3}}=\frac{S_{1}-P_{p}}{S_{3}-P_{p}}=\left(\sqrt{\mu^{2}+1}+\mu\right)
$$

where $\sigma_{1}$ and $\sigma_{3}$ are the effective maximum and minimum principal stresses, respectively, $P_{\mathrm{p}}$ is pore pressure, and $\mu$ is internal friction. Here, we use the internal friction $\mu$ of 0.45-0.62 from Stipp et al. (2013), to constrain the size of the stress polygons. $S_{1}$ and $S_{3}$ correspond to the vertical stress $(\mathrm{Sv})$, the maximum horizontal stress (SHmax), or the minimum horizontal stress (Shmin), depending on fault type (normal fault regime [NF], strikeslip fault regime [SS], or reverse fault regime [RF]). Equation (2) is expressed by three lines in the SHmaxShmin space, defining the stress polygon (Fig. 6). Sv was calculated based on the depth and density of sediments for the fault slip data at $400 \mathrm{~m}$ for site C0001 and 1000 $\mathrm{m}$ for site C0002, which implies that the faults were

Table 2 Stress axis orientation and stress ratio estimated from core-scale fault inversion and directions of SHmax

\begin{tabular}{|c|c|c|c|c|c|c|c|c|}
\hline & \multicolumn{2}{|l|}{ Sigma 1} & \multicolumn{2}{|l|}{ Sigma 2} & \multicolumn{2}{|l|}{ Sigma 3} & \multirow[t]{2}{*}{ Stress ratio } & \multirow{2}{*}{$\begin{array}{l}\text { Used direction } \\
\text { as } S^{\prime}\end{array}$} \\
\hline & Azimuth & Plunge & Azimuth & Plunge & Azimuth & Plunge & & \\
\hline C0001 normal fault & 328 & 83 & 163 & 7 & 73 & 2 & 0.1652 & 328 \\
\hline C0001 thrust fault & 303 & 19 & 38 & 13 & 165 & 66 & 0.8579 & 38 \\
\hline C0002 normal fault & 175 & 82 & 303 & 5 & 33 & 6 & 0.667 & 303 \\
\hline C0002 strike-slip fault & 47 & 17 & 277 & 65 & 143 & 19 & 0.3609 & 47 \\
\hline C0002 thrust fault & 307 & 1 & 38 & 36 & 216 & 46 & 0.6439 & 307 \\
\hline
\end{tabular}

$\mathrm{S}^{\prime}$ indicates the direction of the maximum horizontal stress 


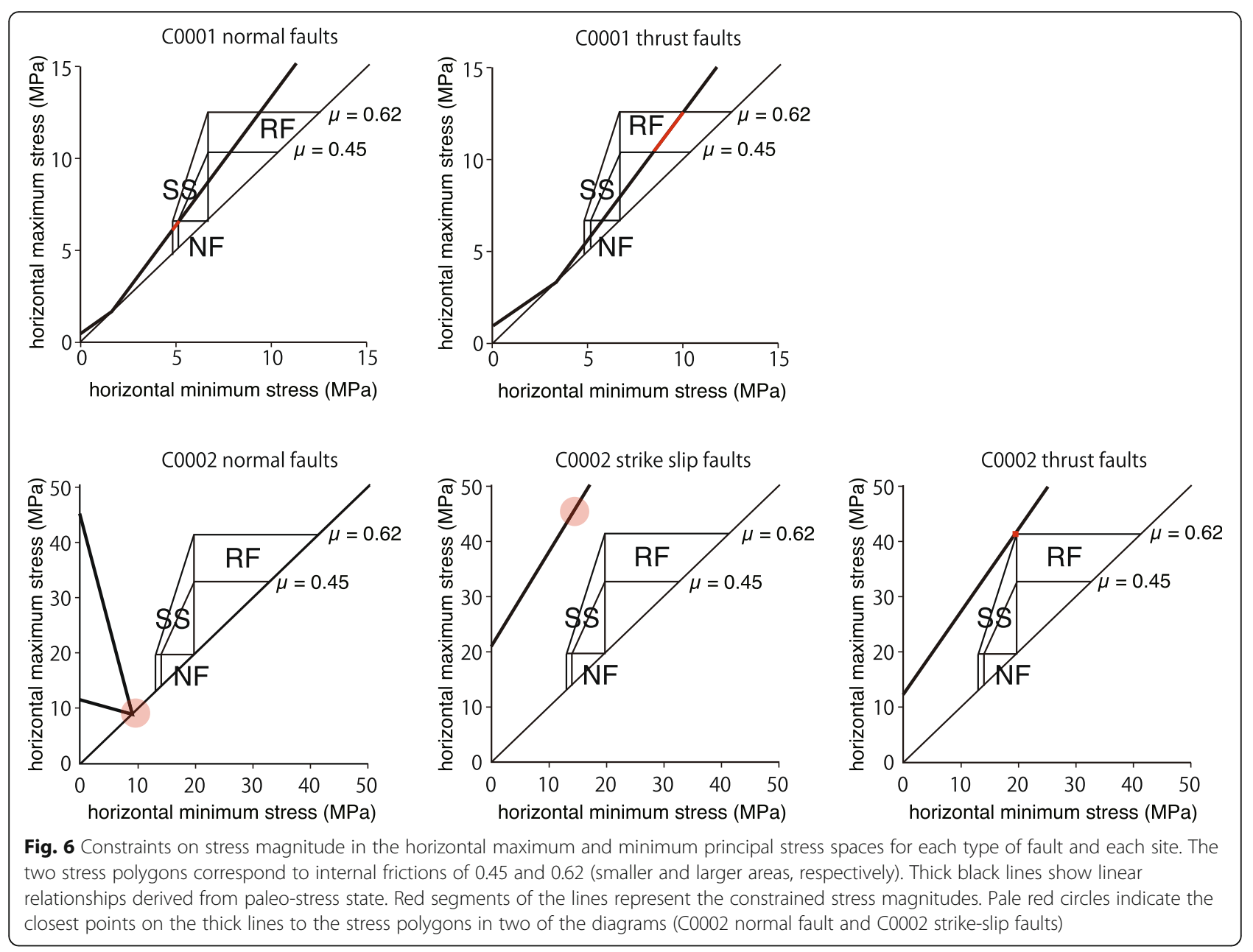

developed at these depths. This assumption will be discussed later. The assumed densities of the sediments are $1.7 \mathrm{~g} / \mathrm{cm}^{3}$ for site $\mathrm{C} 0001$ and $2.0 \mathrm{~g} / \mathrm{cm}^{3}$ for site C0002. Pore pressure is assumed to be hydrostatic. Although the internal friction was determined from more shallow samples, we use these values also for the sediments at $400 \mathrm{mbsf}$ and $1000 \mathrm{mbsf}$. This assumption is possibly inaccurate but it introduces a minor uncertainty in comparison to the weak constraints on the stress magnitude.

The stress states estimated by core-scale fault inversion were projected onto Sv, SHmax, and Shmin. Stress summations were written as follows:

$$
\begin{aligned}
& S_{v}=\sigma_{1} \sin d_{1}+\sigma_{2} \sin d_{2}+\sigma_{3} \sin d_{3} \\
& S^{\prime}=\sigma_{1} \cos d_{1} \cdot \cos \theta_{1}+\sigma_{2} \cos d_{2} \cdot \cos \theta_{2}+\sigma_{3} \cos d_{3} \cdot \cos \theta_{3}
\end{aligned}
$$

$S^{\prime \prime}=\sigma_{1} \cos d_{1} \cdot \sin \theta_{1}+\sigma_{2} \cos d_{2} \cdot \sin \theta_{2}+\sigma_{3} \cos d_{3} \cdot \sin \theta_{3}$

where $S^{\prime}$ and $S^{\prime \prime}$ are SHmax and Shmin; $d_{1}, d_{2}$, and $d_{3}$ are the plunges of the subscripted principal stress axis; and $\theta_{1}, \theta_{2}$, and $\theta_{3}$ are the angles between $S^{\prime}$ or $S^{\prime \prime}$ and the subscripted principal stress axis projected on the horizontal surface (i.e., their trends). The stress ratio obtained from the core-scale fault inversion is adopted as well. Combining Eqs. (1), (3), (4), and (5), linear relationships between SHmax and Shmin can be converted from inverted stresses for each fault type and site. For the conversion, $\sigma_{1}, \sigma_{2}$, and $\sigma_{3}$ are substituted to receive these linear relationships between SHmax and Shmin (see Hashimoto et al. 2015, for details). The direction of S' was taken as the direction of $\sigma_{1}$ or $\sigma_{2}$ that satisfied the linear relationships in the range of SHmax $>$ Shmin. The stress magnitudes determined in this way are used as limits on viable stress conditions for the faulted sediments recovered in the cores from sites C0001 and C0002. These constraints are displayed in the stress polygons (red segments, Fig. 6). The size of the stress polygons is restricted to the internal friction values of $0.45-0.62$.

At site C0001, the stress magnitude for normal faults is constrained to be $\sim 5 \mathrm{MPa}$ for Shmin and $\sim 6 \mathrm{MPa}$ for SHmax, whereas that for thrust faults is in the range of 
9-11 MPa for Shmin and 11-13 MPa for SHmax (Fig. 6). At site C0002, the stress magnitudes for normal faults and strike-slip faults could not be constrained within the stress polygons, but close to the polygons. They can be reasonably limited to be $\sim 10 \mathrm{MPa}$ for both Shmin and SHmax in the case of normal faults and larger, i. e., 14 MPa for Shmin and $45 \mathrm{MPa}$ for SHmax in the case of strike-slip faults. The stress magnitude for thrust faults at site $\mathrm{C} 0002$ ranges from $\sim 20 \mathrm{MPa}$ for Shmin to $\sim 41 \mathrm{MPa}$ for SHmax. Our results indicate lower stress magnitudes for the normal faulting regime and larger stress magnitudes for the strike-slip and reverse faulting regimes (Fig. 6). Importantly, however, the stress magnitude results for site $\mathrm{COO02}$ are not well-constrained.

\section{Implications}

Our results suggest that an integrative approach to unravel stress history, including stress magnitude, is feasible for accretionary wedge settings and potentially very useful to better understand subduction zone processes and controlling parameters in general. The approach includes (1) documenting core-scale faults, (2) inverting these for partial stress tensors, (3) characterizing material properties via triaxial compression testing, and (4) synthesizing the results in stress polygon space to evaluate stress magnitude. Our results are based on a small fault kinematic data set, emphasizing the need for additional coring in these settings wherever possible.

We find relatively large variations in stress magnitude that have implications for understanding the seismic cycle of the Nankai subduction system. In particular, we find higher stress magnitudes for thrust faulting and possibly strike-slip faulting and lower stress magnitudes for normal faulting. The differences in stress magnitude are achieved by a larger change in the horizontal maximum principal stress and a smaller change in the horizontal minimum principal stress (Fig. 6), suggesting that the overall tectonic stress state generating the horizontal stress changes from thrust or strike-slip faults to normal faults and vice versa. Similar stress changes have been reported in previous studies in onland fold-and-thrust systems (Hashimoto et al. 2014; Hashimoto et al. 2015). They discussed that the stress changes can possibly result from the seismic cycle, in which the tectonic stress released by a large earthquake causing a decrease in horizontal maximum principal stress to a value lower than the vertical gravitational stress. This scenario might correspond to the case of this study at least for the results of site C0001.

Alternatively, the stress variations we document reflect the exhumation process for the shallow structural levels of the accretionary wedge rather than the seismic cycle. Borehole observations and anelastic strain recovery measurements indicate the normal fault stress state in the shallow portion of the accretionary wedge where vertical stress is the maximum principal stress at site $\mathrm{C} 0002$ (e.g., Lin et al. 2015). Kitajima et al. (2017) recently determined the stress regime in the deeper portion of the wedge (around 1500-3000 mbsf at site C0002) where the strike-slip fault regime was recognized and the reverse fault regime can be expected to occur below. Such variations in stress regime with depth are reasonable because the horizontal tectonic stress will increase toward the plate interface (e.g., Wang and $\mathrm{Hu} 2006$ ).

The interpretation that the stress regime changes with exhumation of the sediments implies that the vertical movement of the sediments must account for more than $2000 \mathrm{~m}$ if we assume a simple vertical uplift of the sediments from the thrust or strike-slip fault to the normal fault regime. However, the stress state at site C0002 is characteristic of the strike-slip regime down to $3000 \mathrm{mbsf}$ (Kitajima et al. 2017). The consolidation state of sediments encountered at $\sim 1000 \mathrm{mbsf}$ at site C0002 suggests little to no uplift (Kitajima and Saffer 2012). Therefore, simple vertical uplift is not reasonable at this position. Alternatively, Fukuchi et al. (2017) found that the paleo-geothermal gradient at site $\mathrm{C0002}$ estimated from vitrinite reflectance is larger than the current geothermal gradient and proposed that the high paleo-geothermal gradient can be a paleo-record of the frontal prism area where a high geothermal gradient is also observed at present. It is also possible that the reverse faults were developed close to the frontal thrust and the sediments were transported into the normal fault regime during growth and seaward propagation of the accretionary wedge. Consequently, our assumption that the thrust and normal faults were developed at the same depth would not be appropriate in this scenario. Hence, the tectonic evolution of the accretionary wedge is probably the most important reason why the results of site $\mathrm{C0002}$ are not well-constrained. Another explanation for a changing stress regime at site $\mathrm{C0002}$ is the difference in age (Pleistocene for shallow samples and Miocene for core-scale faults) allowing for tectonic changes over this time period. Furthermore, internal friction could vary significantly with depth. If internal friction increases toward depth, the stress polygon will become larger. We used a maximum value of 0.62 for internal friction taking a wide variability with depth into account.

For site C0001, although the model of a growing accretionary prism can be proposed, the current reverse fault regime is also conceivable. Thrust fault activity at shallow level was proven by frictional heating along the megasplay fault (Sakaguchi et al. 2011). Site C0001 is located at the upper slope and close to the megasplay fault. In this case, any stress change at site C0001 could be caused by seismic cycling. 


\section{Conclusions}

Constraints on paleo-stress magnitude were obtained through integration of paleo-stress states estimated from core-scale fault inversion with mechanical laboratory data obtained from triaxial compression tests on samples from the shallow Nankai accretionary wedge in the upper slope and forearc basin areas. In result, possible stress magnitudes of normal faults are smaller than those of thrust faults, which is consistent with previous studies on exhumed accretionary complexes on land. The stress magnitudes for the sediments of the forearc basin (site C0002) are higher than those for the upper slope (site C0001), but inherent errors by combining the structural and geotechnical data are relatively large. The change in stress state and stress magnitude observed in this study can be caused by the tectonic evolution of the accretionary wedge or by variations in the seismic cycle.

\section{Abbreviations}

ASTM: American Society for Testing and Materials; IODP: Integrated Ocean Drilling Program; NanTroSEIZE: Nankai Trough Seismogenic Zone Experiment

\section{Acknowledgements}

We would like to thank Ralf Doose, Detlef Schulte-Kortnack, and Robert Kurzawski for their assistance in the laboratory experiments. The samples for this study were provided from a series of IODP Expeditions in NanTroSEIZE. Robert Kurzawski kindly provided the original drawing of Fig. 3. Reviewers Prof. Kyuichi Kanagawa and Prof. Weiren Lin made important suggestions, which significantly improved the manuscript.

\section{Funding}

This research was supported by JSPS KAKENHI Grant Numbers JP15H03738 and JP15KK0170.

\section{Availability of data and materials}

Please contact author for data requests.

\section{Authors' contributions}

$\mathrm{YH}$ proposed, conceived, and designed the study. MS and FW worked on laboratory experiments together with $\mathrm{YH}$. JL contributed to the structural analysis. All authors were involved in the discussion and writing and approval of the final manuscript.

\section{Competing interests}

The authors declare that they have no competing interests.

\section{Publisher's Note}

Springer Nature remains neutral with regard to jurisdictional claims in published maps and institutional affiliations.

\section{Author details}

${ }^{1}$ Kochi University, Akebonocho 2-5-1, Kochi 780-8520, Japan.

${ }^{2}$ Martin-Luther-University, Von-Seckendorff-Platz 3, 06120 Halle, Germany.

${ }^{3}$ Indiana University of Pennsylvania, 302 East Walk, Indiana, PA 15705, USA.

${ }^{4}$ Kiel University, Ludewig-Meyn-Straße 10, 24118 Kiel, Germany.

Received: 29 April 2018 Accepted: 6 December 2018

Published online: 15 January 2019

\section{References}

Angelier J (1984) Tectonic analysis of fault slip data sets. J Geophys Res 89:5835-5848

Ashi J, Lallemant S, Masago H, the Expedition 315 Scientists (2009) Expedition

315 summary. In M. Kinoshita, et al. (Eds.), Proceedings of the Integrated

Ocean Drilling Program, 314/315/316. Washington, DC: Integrated Ocean
Drilling Program Management International, Inc. doi:https://doi.org/10.2204/ iodp.proc.314315316.121.2009

Byrne TB, Lin W, Tsutsumi A, Yamamoto Y, Lewis JC, Kanagawa K, Kimura G (2009) Anelastic strain recovery reveals extension across SW Japan subduction zone. Geophys res let 36(23). https://doi.org/10.1029/ 2009GL040749

Chang C, McNeill LC, Moore JC, Lin W, Conin M, Yamada Y (2010) In situ stress state in the Nankai accretionary wedge estimated from borehole wall failures. Geochem Geophys Geosys. 11:Q0AD04

Fukuchi R, Yamaguchi A, Yamamoto Y, Ashi J (2017) Paleothermal structure of the Nankai inner accretionary wedge estimated from vitrinite reflectance of cuttings. Geochem Geophys Geosys 18(8):3185-3196

Hashimoto Y, Eida M, Ueda Y (2014) Changes in paleostress state along a subduction zone preserved in an on-land accretionary complex, the Yokonami mélange in the Cretaceous Shimanto Belt, Kochi, Southwest Japan. Tectonics 33:2045-2058

Hashimoto Y, Tobe K, Yeh EC, Lin W, Song SR (2015) Changes in paleostress and its magnitude related to seismic cycles in the Chelung-pu fault, Taiwan. Tectonics 34:2419-2428

Kimura G, Koge H, Tsuji T (2018) Punctuated growth of an accretionary prism and the onset of a seismogenic megathrust in the Nankai trough. Prog Earth Planet Sci 5(1):78. https://doi.org/10.1186/s40645-018-0234-1

Kitajima H, Saffer D, Sone H, Tobin H, Hirose T (2017) In situ stress and pore pressure in the deep interior of the Nankai accretionary prism, Integrated Ocean Drilling Program Site C0002. Geophys Res Lett 44:9644-9652

Kitajima H, Saffer DM (2012) Elevated pore pressure and anomalously low stress in regions of low frequency earthquakes along the Nankai trough subduction megathrust. Geophys res let. https://doi.org/10.1029/2012gl053793

Lewis JC, Byrne TB, Kanagawa K (2013) Evidence for mechanical decoupling of the upper plate at the Nankai subduction zone: constraints from core-scale faults at NantroSEIZE sites C0001 and C0002. Geochem Geophys Geosys. 4: 620-633

Lin W, Byrne TB, Kinoshita M, McNeill LC, Chang C, Lewis JC, Yamamoto Y, Saffer DM, Moore JC, Wu H-Y (2015) Distribution of stress state in the Nankai subduction zone, Southwest Japan and a comparison with Japan trench. Tectonophys. https://doi.org/10.1015/j.tecto.2015.05.008

Lin W, Conin M, Moore JC, Chester FM, Nakamura Y, Mori JJ, Anderson L, Brodsky EE, Equchi N, Cook B (2013) Stress state in the largest displacement area of the 2011 Tohoku-Oki earthquake. Science 339(6120):687-690

Lin W, Yeh E-C, Ito H, Hung J-H, Hirono T, Soh W, Ma K-F, Kinoshita M, Wang C-Y, Song S-R (2007) Current stress state and principal stress rotations in the vicinity of the Chelungpu fault induced by the 1999 Chi-Chi, Taiwan, earthquake. Geophys Res Lett 34:L16307

Miyazaki S, Heki K (2001) Crustal velocity field of Southwest Japan: subductionand arc-arc collision. J Geophys Res 106:4305-4326

Oohashi K, Lin W, Wu HY, Yamaguchi A, Yamamoto Y (2017) Stress state in the Kumano Basin and in slope sediment determined from Anelastic strain recovery: results from IODP Expedition 338 to the Nankai trough. Geochem Geophys Geosys. 18:3608-3616

Park JO, Tsuru T, Kodaira S, Cummins PR, Kaneda Y (2002) Splay fault branching along the Nankai subduction zone. Science 297(5584):1157-1160

Sakaguchi A, Chester F, Curewitz D, Fabbri O, Goldsby D, Kimura G, Li C-F, Masaki Y, Screaton EJ, Tsutsumi A (2011) Seismic slip propagation to the updip end of plate boundary subduction interface faults: Vitrinite reflectance geothermometry on Integrated Ocean Drilling Program NanTro SEIZE cores. Geology 39:395-398

Schumann K, Behrmann JH, Stipp M, Yamamoto Y, Kitamura Y, Lempp C (2014a) Geotechnical behavior of mudstones from the Shimanto and Boso accretionary complexes, and implications for the Nankai accretionary prism. Earth, planets and space. https://doi.org/10.1186/1880-5981-66-129

Schumann K, Stipp M, Leiss B, Behrmann JH (2014b) Texture development in naturally compacted and experimentally deformed silty clay sediments from the Nankai trench and Forearc, Japan. Tectonophys 636:125-142

Seno T, Stein S, Gripp AE (1993) A model for the motion of the Philippine Sea plate consistent with NUVEL-1 and geological data. J Geophys Res 98:17941-17948

Stipp M, Rolfs M, Kitamura Y, Behrmann JH, Schumann K, Schulte-Kortnack D, Feeser V (2013) Strong sediments at the deformation front, and weak sediments at the rear of the Nankai accretionary prism, revealed by triaxial deformation experiments. Geochem Geophys Geosys. 14:4791-4810

Tobin H, Kinoshita M, Moe K T, the Expedition 314 Scientists (2009) Expedition 314 summary. In M. Kinoshita et al. (Eds.), Proceedings of the Integrated 
Ocean Drilling Program, 314/315/316. Washington, DC: Integrated Ocean Drilling Program Management International, Inc. doi:https:/doi.org/10.2204/ iodp.proc.314315316.111.2009

Wang K, Hu Y (2006) Accretionary prisms in subduction earthquake cycles: the theory of dynamic Coulomb wedge. J Geophys Res 111:B06410

Wu H-Y, Ma K-F, Zoback M, Boness N, Ito H, Hung J-H, Hickman S (2007) Stress orientations of Taiwan Chelungpu-Fault Drilling Project (TCDP) hole-A as observed from geophysical logs. Geophys Res Lett. https://doi.org/10.1029/ 2006GL028050

Yamaji A (2000) The multiple inverse method: a new technique to separate stresses from heterogeneous fault-slip data. J Struct Geol 22(4):441-452

Yamaji A, Otsubo M, Sato K (2006) Paleostress analysis using the Hough transform for separating stresses from heterogeneous fault-slip data. J Struct Geol 28:980-990

Zoback MD, Barton CA, Brudy M, Castillo DA, Finkbeiner T, Grollimund BR, Moos DB, Peska P, Ward CD, Wiprut DJ (2003) Determination of stress orientation and magnitude in deep wells. Internat J Rock Mechan Mining Sci 40:1049-1076

\section{Submit your manuscript to a SpringerOpen ${ }^{\circ}$ journal and benefit from:}

- Convenient online submission

- Rigorous peer review

- Open access: articles freely available online

- High visibility within the field

- Retaining the copyright to your article

Submit your next manuscript at $\boldsymbol{\triangleright}$ springeropen.com 